\title{
STUDIES ON ENTEROTOXIGENIC STAPHYLOCOCCUS AUREUS IN MILK AND SOME DAIRY PRODUCTS
}

\author{
ARAFA M.S. MESHREF ${ }^{1}$; GAMAL M. HASSAN ${ }^{1}$; EMAD M. RIAD ${ }^{2}$ and \\ WALAA A. ASHOUR ${ }^{3}$ \\ ${ }^{1}$ Food Safety and Technology Department, Faculty of Veterinary Medicine, Beni-Suef University, Egypt. \\ ${ }^{2}$ Bacteriology Department, Animal Health Research Institute, Egypt. \\ ${ }^{3}$ Animal Health Research Institute, Beni-Suef Branch, Beni-Suef, Egypt.
}

Received: 26 September 2019; Accepted: 17 October 2019

\begin{abstract}
Staphylococcus aureus is one of the commonest aetiological agents of bacterial diseases. Food intoxication by S.aureus was listed as the third etiology of food intoxication all over the world. The current study was designed to record the prevalence of $S$. aureus in milk and some dairy products. A total of 200 samples consisting of (25 raw cow's milk, 25 raw buffalo's milk, 50 kareish cheese, 25 small scale ice-cream, 25 large scale ice-cream, 25 small scale yoghurt and 25 large scale yoghurt samples) were collected from dairy shops and street vendors in Beni-Suef Governorate, Egypt. The prevalence rate of S. aureus was 13 (52\%), 16 (64\%), 34 (68\%), 20 (80\%), 6 $(24 \%), 22(88 \%)$ and $9(36 \%)$ with an average count of $1.62 \times 10^{8} \pm 9.5 \times 10^{7}, 7.88 \times 10^{7} \pm 5.19 \times 10^{7} \mathrm{CFU} / \mathrm{ml}$, $8.68 \times 10^{7} \pm 2.61 \times 10^{7}, 6.64 \times 10^{7} \pm 3.29 \times 10^{7}, 6.52 \times 10^{5} \pm 4.41 \times 10^{5}, 3.67 \times 10^{6} \pm 1.68 \times 10^{6}$ and $5.27 \times 10^{5} \pm$ $3.45 \times 10^{5} \mathrm{CFU} / \mathrm{g}$ in the concering samples, respectively. The molecular results confirmed that $30 \%$ of the examined $S$. aureus strains were enterotoxigenic by PCR technique as carried one or two SE-genes. High $S$. aureus counts in milk and milk products constitute a public health hazard to the consumers and emphasizes the need for improved hygienic standards.
\end{abstract}

Key words: S. aureus, Milk, Kareish cheese, Ice-cream, Yoghurt, Enterotoxins, PCR.

\section{INTRODUCTION}

Milk is a highly nutritious food that serves as an excellent growth medium for a wide range of food borne pathogens (Richter et al., 1992). In Egypt, direct consumption of raw milk is much frequent and more popular than consumption of pasteurized one because it's believed, especially in rural areas, that raw milk and its byproducts have nutritional advantages over the pasteurized one. Furthermore, milk is produced mainly by individual in small farms that lack proper sanitary measures and may be either consumed fresh, manufactured into dairy products or sell in retail markets that alarming as a major source of Staphylococcal enterotoxin poisoning (El-Sayed et al., 2011) and represent a serious human health problem.

Kareish cheese is considered one of the most food products rich in calcium and phosphorus. These elements are essential for bones and teeth formation, it is also rich in sodium and potassium, which play an important role in the formation of body liquids and muscles (Mahmoud et al., 2013). Ice-cream is a

Corresponding author: Dr. Walaa. A. Ashour E-mail address: ashour.walaa91@yahoo.com

Present address: Animal Health Research Institute, Beni-suef Branch, Beni-suef, Egypt. nutritionally enriched congealed dairy product consumed by all age groups particularly children during summer (El-Sharef et al., 2006). Yoghurt is the best known of all cultured milk products and the most popular almost all over the world. Consumption of fermented milk products are associated with several types of human health benefits, including it's potential effect against development of colon tumers (Wollowski et al., 2001), reducing risk of hypertension, improving lactose digestion, preventing diarrhea, reducing serum cholesterol (McDonagh et al., 1997).

Dairy products are liable to be contaminated with $S$. aureus from different sources during their production, processing and handling that make them unfit for human consumption or even a dangerous source of infection among consumers constituting a potential health hazard caused by enterotoxin production. This can be occurred under certain conditions during production as well as when they are cut and packaged for consumption (Wauschkuhm, 1970).

$S$. aureus is a Gram-positive microorganism that colonizes the nasal passages and skin of approximately $50 \%$ of healthy individuals. S. aureus grows in a wide range of temperatures and $\mathrm{pH}$, from $7{ }^{\circ} \mathrm{C}$ to $48.5{ }^{\circ} \mathrm{C}$, and 4.2 to 9.3 , respectively. $S$. 
aureus can adapt to grow in various foods and causes food poisoning by secreting enterotoxins (Balaban and Rasooly, 2000).

Staphylococcal Food Poisoning is one of the most commonly occurring Food Borne Disease (FBD) worldwide with high occurrence second to salmonellosis (Aycicek et al., 2005). The significance of finding $S$. aureus in foods suspected of causing staphylococcal poisoning should be interpreted with caution (Robinson and Tamime, 2002). Up to $50 \%$ of humans may carry this organism in their nasal passages, throats and on their hair and skin. So it is good indicator of the personal hygiene of the workers with a respiratory infections (Kamat et al., 1991).

The staphylococcal enterotoxins (SEs) are recognized agents of the staphylococcal food poisoning syndrome and may be involved in other types of infections with sequelae of shock in humans and animals (Bergdoll, 1983). Nine major antigenic types of SEs have been recognized and designated SEA, SEB, SEC, SED, SEE, SEG, SEH, SEI, and SEJ (Betley and Mekalanos, 1987). The most common symptoms resulting from the ingestion of food contaminated by SEs are nausea, vomiting, diarrhea and abdominal cramps, which occur within 2-6 hrs of eating SE-contaminated food (Tranter, 1990). Further SE toxins have been identified (SEK, SEL, SEM, SEN, SEO and SEU) (Orwin et al., 2001). It is known that about $95 \%$ of staphylococcal food poisoning outbreaks are caused by SE types SEA to SEE (Bergdoll, 1983).

Enterotoxins have been detected by various methods, but the PCR technique has the ability of detecting specific gene sequences by DNA amplification (Omoe et al., 2002). PCR is much faster and can be applied to detect SEs in most kinds of food such as milk and cheese products rather than available conventional techniques (compared with animal tests) (Shijia et al., 2016).

The presence of $S$. aureus in milk and dairy product are not only of economic importance, but also constitute a public health hazard. Therefore, the present work was planned to investigate the incidence of $S$. aureus in milk and some dairy products and to throw the light upon the public health significance, preventive and control measures of $S$. aureus.

\section{MATERIALS AND METHODS}

Part I: Isolation and identification of $S$. aureus: I-1- Collection and handling of the samples:

A total of 200 samples consisting of 25 raw cow's milk, 25 raw buffalo's milk, 50 kareish cheese, 25 small scale ice-cream, 25 large scale ice-cream, 25 small scale yoghurt and 25 large scale yoghurt samples were collected from dairy shops and street vendors in Beni-Suef Governorate, Egypt. The collected samples were delivered as soon as possible to the laboratory in an insulated ice box and examined in the same day. Each milk sample was thoroughly mixed before divided into two parts. The first part was used for Storch's test (Lampert., 1987) to exclude the heat treated milk, while the second one was used for bacteriological examination.

\section{I-2- Preparation, Enumeration and identification of $S$. aureus according to (Quinn et al., 1994):}

Raw milk and yoghurt samples were thoroughly mixed before preparation of serial dilutions, while ice-cream samples were melted in thermostatically controlled water bath at a temperature of up to $40^{\circ} \mathrm{C}$ for not more than $15 \mathrm{~min}$ and mixed well. Eleven $\mathrm{ml} /$ grams of samples were diluted in $99 \mathrm{ml}$ of sterile $0.1 \%$ peptone water for initial dilution, subsequent decimal dilutions were prepared with the same diluent. Eleven grams of kareish cheese samples were transferred into a sterile blender and thoroughly homogenized with $99 \mathrm{ml}$ of sterile $2 \%$ sodium citrate solution to obtain a dilution of $1: 10$, and then serial dilutions were carried out.

From each dilution $0.1 \mathrm{ml}$ was spread onto a dry surface of double sets of Baird-Parker agar plate supplemented with egg yolk tellurite emulsion. The streaked plates were incubated at $37^{\circ} \mathrm{C}$ for $24-48 \mathrm{~h}$. Typical colonies of $S$. aureus (black shining convex colonies, 1-1.5 $\mathrm{mm}$ in diameter with narrow white margin and surrounded by a clear zone extending into opaque medium) were selected and isolated. The isolates were subjected to further microscopic and biochemical identification (Catalase test, Coagulase test, Mannitol salt agar medium) as described by (Quinn et al., 1994).

\section{Part II: Detection of enterotoxins genes of $S$. aureus by PCR:}

\section{1- Extraction of DNA according to QIAamp DNA mini kit instructions (Mehrotra et al., 2000):}

$20 \mu \mathrm{l}$ QIAGEN protease were pipetted into the bottom of a $1.5 \mathrm{ml}$ microcentrifuge tube, then add $200 \mu \mathrm{l}$ of the sample and $200 \mu \mathrm{l}$ buffer AL, mixed by pulse vortexing for 15 seconds. After that the mixture was incubated at $56^{\circ} \mathrm{C}$ for $10 \mathrm{~min}$ and centrifugated to remove drops from the inside of the lid. $200 \mu \mathrm{l}$ ethanol (96\%) were added to the sample, and mixed again by pulse vortexing for 15 seconds. After mixing, make centrifugation to remove drops from the inside of the lid. The solution was carefully transferred to the QIAamp mini spin column (in a $2 \mathrm{ml}$ collecting tube) without wetting the rim. the cap was closed, and centrifugated at $8000 \mathrm{rpm}$ for $1 \mathrm{~min}$. The QIAamp mini spin column contents were transferred into a clean $2 \mathrm{ml}$ collection tube, and the tube containing the filtrate was discarded, after 
centrifugation. Then add $500 \mu \mathrm{l}$ buffer AW1 was added without wetting the rim. The cap was closed, centrifugated at $8000 \mathrm{rpm}$ for $1 \mathrm{~min}$ and $500 \mu \mathrm{l}$ buffer AW2 were added. The cap was closed, and centrifugated at full speed for $3 \mathrm{~min}$. The old collection tube was discarded with the filtrate. Centrifugation at full speed for 1 min was done. After that the QIAamp mini spin column was transferred to a clean $1.5 \mathrm{ml}$ microcentrifuge tube, and the collection tube containing the filtrate was discarded. It was carefully opened and $100 \mu \mathrm{l}$ buffer $\mathrm{AE}$ were added and incubated at room temperature $\left(15-25^{\circ} \mathrm{C}\right)$ for $1 \mathrm{~min}$ and then centrifugated at 8000 rpm for $1 \mathrm{~min}$.

2- Cycling conditions of the primers during cPCR:

Temperature and time conditions of the primers during PCR are shown in Table:

\begin{tabular}{cccccc}
\hline $\begin{array}{c}\text { Primary } \\
\text { denaturation }\end{array}$ & $\begin{array}{c}\text { Secondary } \\
\text { denaturation }\end{array}$ & Annealing & Extension & $\begin{array}{c}\text { No. of } \\
\text { cycles }\end{array}$ & $\begin{array}{c}\text { Final } \\
\text { extension }\end{array}$ \\
\hline $94^{\circ} \mathrm{C}$ & $94^{\circ} \mathrm{C}$ & $57^{\circ} \mathrm{C}$ & $72^{\circ} \mathrm{C}$ & 35 & $72^{\circ} \mathrm{C}$ \\
$5 \mathrm{~min}$. & $30 \mathrm{sec}$. & $30 \mathrm{sec}$. & $30 \mathrm{sec}$. & $7 \mathrm{~min}$. \\
\hline
\end{tabular}

\section{3- Agarose gel electrophoreses with modification (Sambrook et al., 1989):}

The gel was photographed by a gel documentation system and the data was analyzed through computer software.

\section{RESULTS}

Table 1: Statistical analytical results of coagulase- positive $S$. aureus in the examined raw milk samples (cfu/ml).

\begin{tabular}{cccccccc}
\hline Samples & $\begin{array}{c}\text { No. of } \\
\text { examined } \\
\text { samples }\end{array}$ & $\begin{array}{c}\text { No. of positive } \\
\text { samples }\end{array}$ & $\%$ & Minimum & Maximum & Mean & \pm SEM \\
\hline Raw cow's milk & $\mathbf{2 5}$ & $\mathbf{1 3}$ & $\mathbf{5 2}$ & $<\mathbf{1 0}$ & $\mathbf{9 . 8} \times \mathbf{1 0}^{\mathbf{8}}$ & $\mathbf{1 . 6 2 \times 1 0 ^ { 8 }}$ & $\mathbf{9 . 5 \times 1 0 ^ { 7 }}$ \\
\hline $\begin{array}{c}\text { Raw buffalo's } \\
\text { milk }\end{array}$ & $\mathbf{2 5}$ & $\mathbf{1 6}$ & $\mathbf{6 4}$ & $<\mathbf{1 0}$ & $\mathbf{8 . 5 \times 1 0 ^ { 8 }}$ & $\mathbf{7 . 8 8 \times 1 0 ^ { 7 }}$ & $\mathbf{5 . 1 9 \times 1 0 ^ { 7 }}$ \\
\hline
\end{tabular}

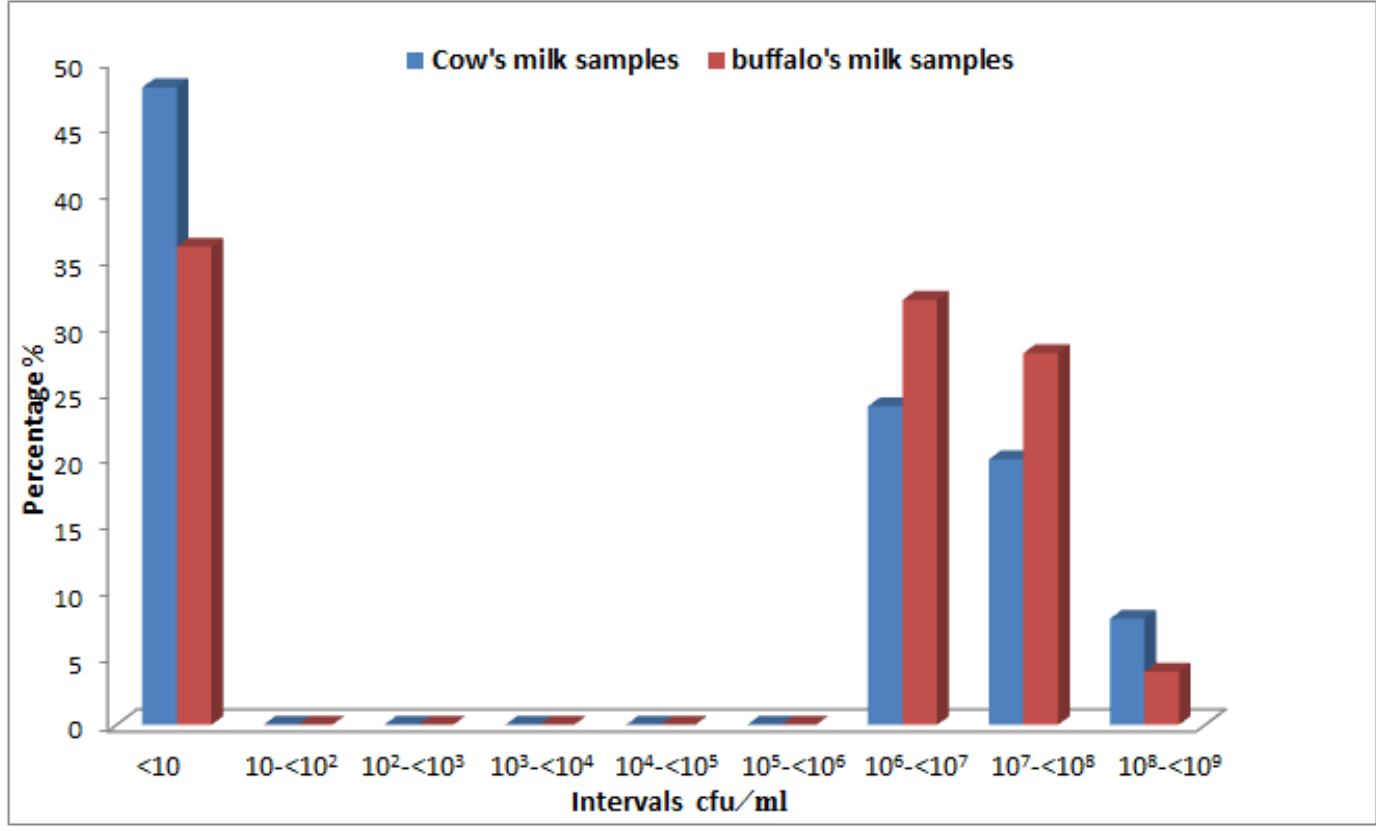

Figure (1): Frequency distribution of $S$. aureus counts $/ \mathrm{ml}$ in the examined raw cow's and buffalo's milk samples. 
Table 2: Statistical analytical results of coagulase- positive $S$. aureus counts in the examined dairy products samples $(\mathrm{cfu} / \mathrm{g})$.

\begin{tabular}{|c|c|c|c|c|c|c|c|}
\hline \multirow[t]{2}{*}{ Samples } & \multirow{2}{*}{$\begin{array}{c}\text { No. of } \\
\text { examined } \\
\text { samples }\end{array}$} & \multicolumn{2}{|c|}{$\begin{array}{l}\text { No. of positive } \\
\text { samples }\end{array}$} & \multirow[t]{2}{*}{ Minimum } & \multirow[t]{2}{*}{ Maximum } & \multirow[t]{2}{*}{ Mean } & \multirow[t]{2}{*}{ \pm SEM } \\
\hline & & No. & $\%$ & & & & \\
\hline Kareish cheese & 50 & 34 & 68 & $<10^{2}$ & $7.3 \times 10^{8}$ & $8.68 \times 10^{7}$ & $2.61 \times 10^{7}$ \\
\hline Small scale ice- cream & 25 & 20 & 80 & $<10^{2}$ & $7.8 \times 10^{8}$ & $6.64 \times 10^{7}$ & $3.29 \times 10^{7}$ \\
\hline Large scale ice- cream & 25 & 6 & 24 & $<10^{2}$ & $1.1 \times 10^{7}$ & $6.52 \times 10^{5}$ & $4.41 \times 10^{5}$ \\
\hline Small scale yoghurt & 25 & 22 & 88 & $<10^{2}$ & $3.2 \times 10^{7}$ & $3.67 \times 10^{6}$ & $1.68 \times 10^{6}$ \\
\hline Large scale yoghurt & 25 & 9 & 36 & $<10^{2}$ & $8.5 \times 10^{6}$ & $5.27 \times 10^{5}$ & $3.45 \times 10^{5}$ \\
\hline
\end{tabular}

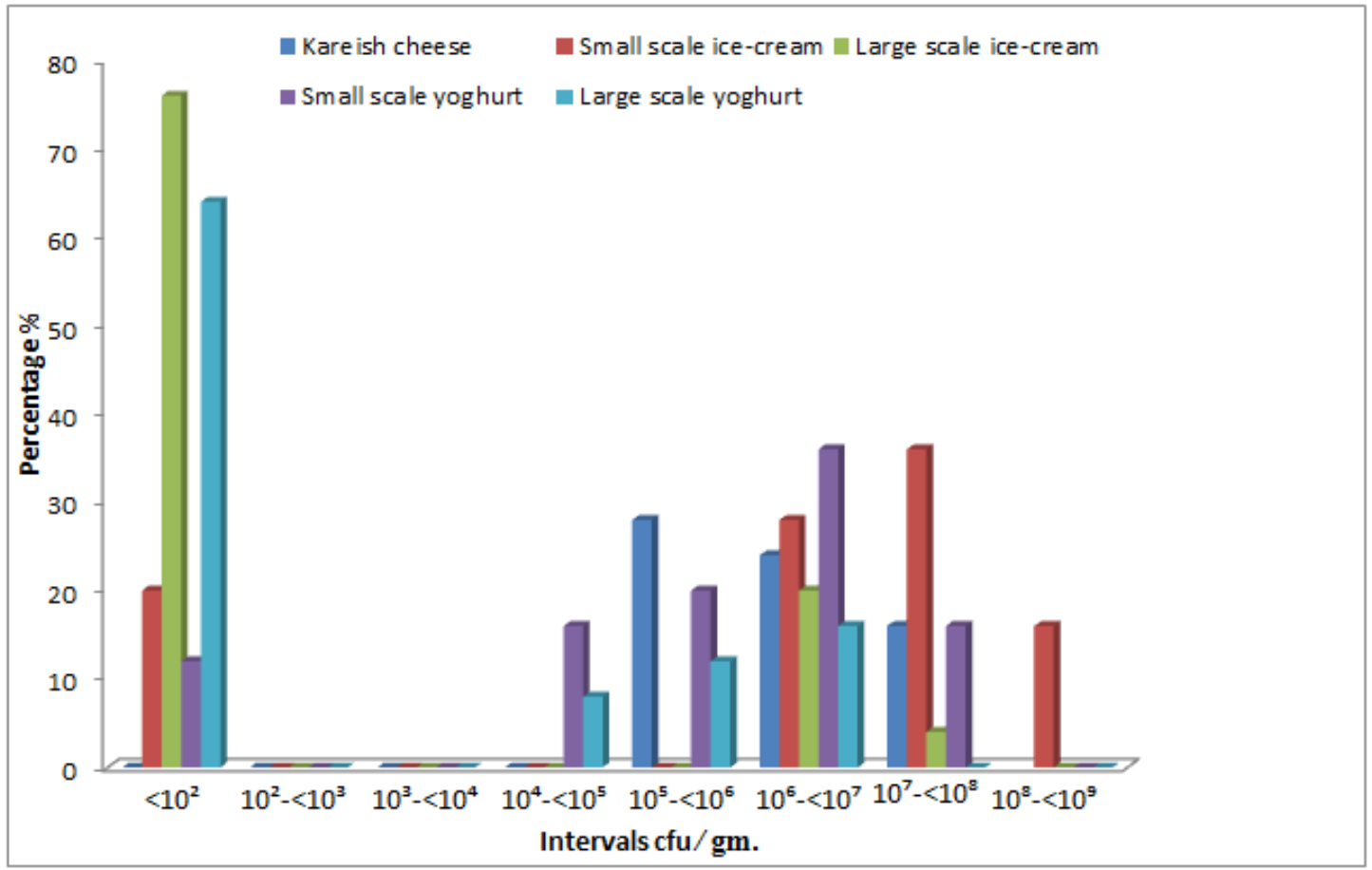

Figure (2): Frequency distribution of coagulase- positive $S$. aureus counts in the examined dairy products samples.

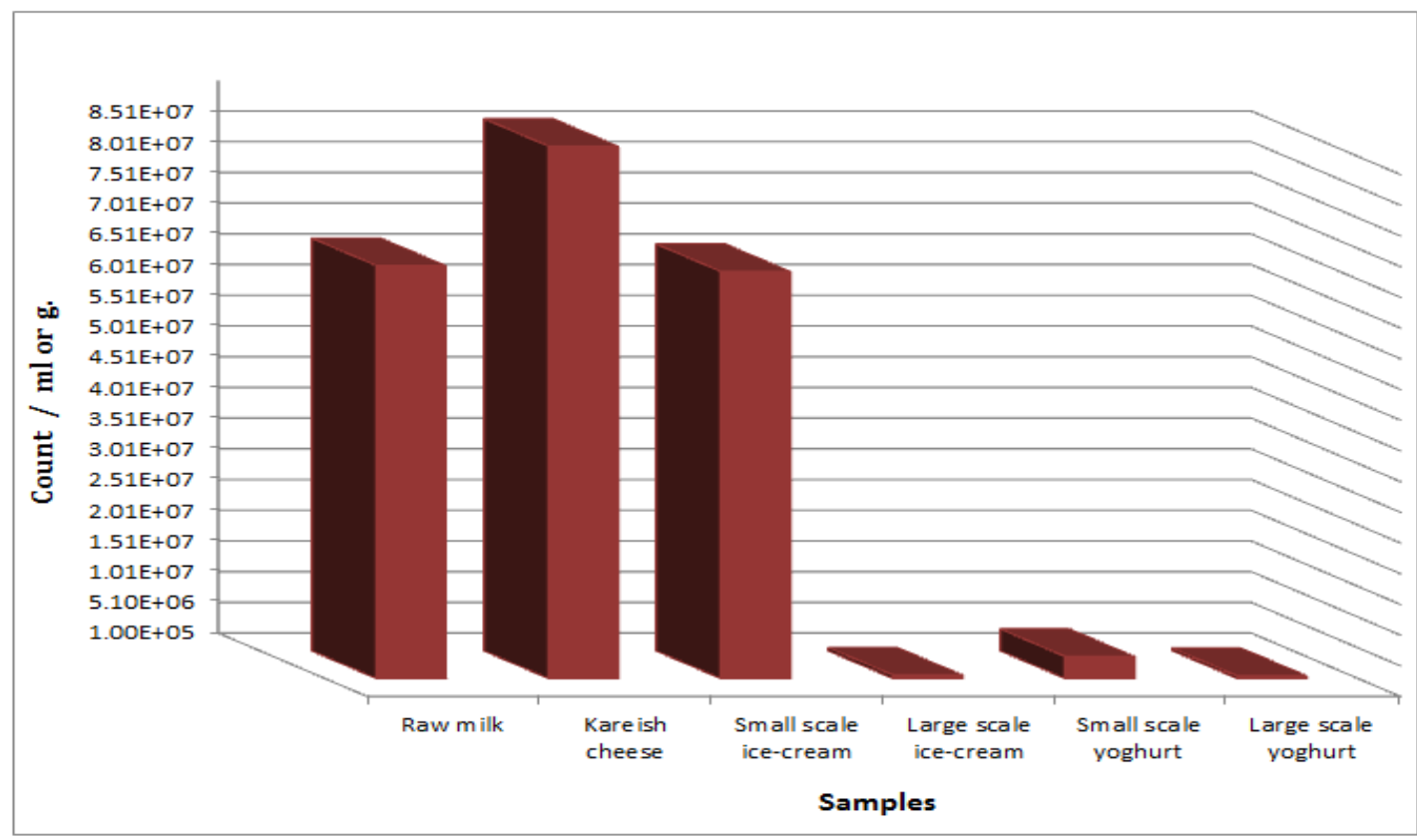

Figure (3): Coagulase- positive S. aureus counts (/ml or g.) in the examined samples. 
Table 3: PCR results for detection entrotoxigenic S. aureus of Sea and Seb toxins.

\begin{tabular}{|c|c|c|c|}
\hline \multirow{2}{*}{ No.of samples } & \multirow{2}{*}{ origin } & \multicolumn{2}{|c|}{ Results } \\
\hline & & Sea & Seb \\
\hline 1 & Yoghurt & - & - \\
\hline 2 & Yoghurt & - & + \\
\hline 3 & Yoghurt & - & - \\
\hline 4 & Yoghurt & - & - \\
\hline 5 & Yoghurt & + & + \\
\hline 6 & Milk & - & + \\
\hline 7 & Milk & - & - \\
\hline 8 & Milk & - & - \\
\hline 9 & Milk & - & - \\
\hline 10 & Milk & + & + \\
\hline 11 & Ice-cream & - & - \\
\hline 12 & Ice-cream & - & - \\
\hline 13 & Ice-cream & - & + \\
\hline 14 & Ice-cream & - & - \\
\hline 15 & Ice-cream & - & - \\
\hline 16 & Kareish cheese & - & - \\
\hline 17 & Kareish cheese & - & - \\
\hline 18 & Kareish cheese & - & - \\
\hline 19 & Kareish cheese & - & + \\
\hline 20 & Kareish cheese & - & - \\
\hline
\end{tabular}

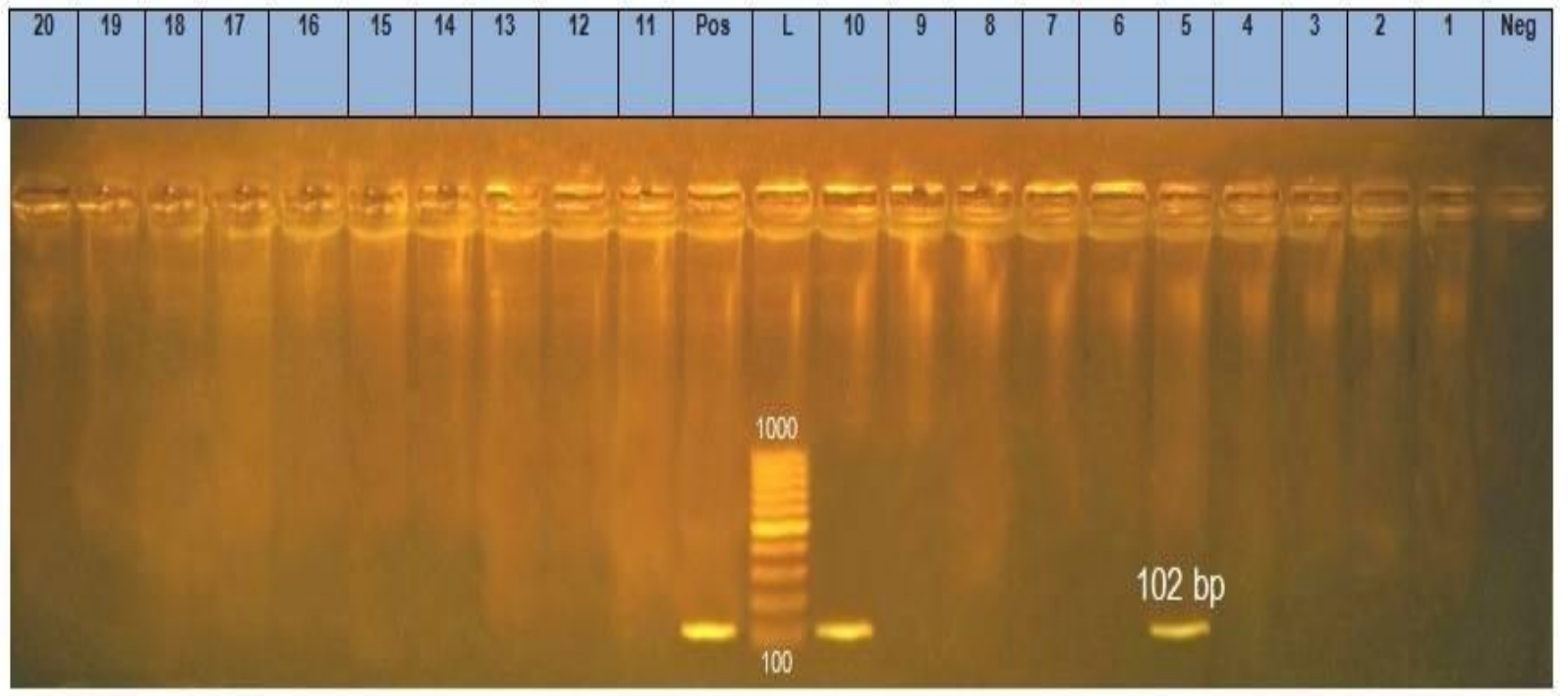

Figure (4): PCR results for S. aureus Sea gene

L: $100-1000$ bp DNA ladder.

Lane 5, 10: positive samples for sea gene.

Lane 1-4,6-9,11-20: negative samples.

Pos.: Positive control.

Neg.: Negative control. 


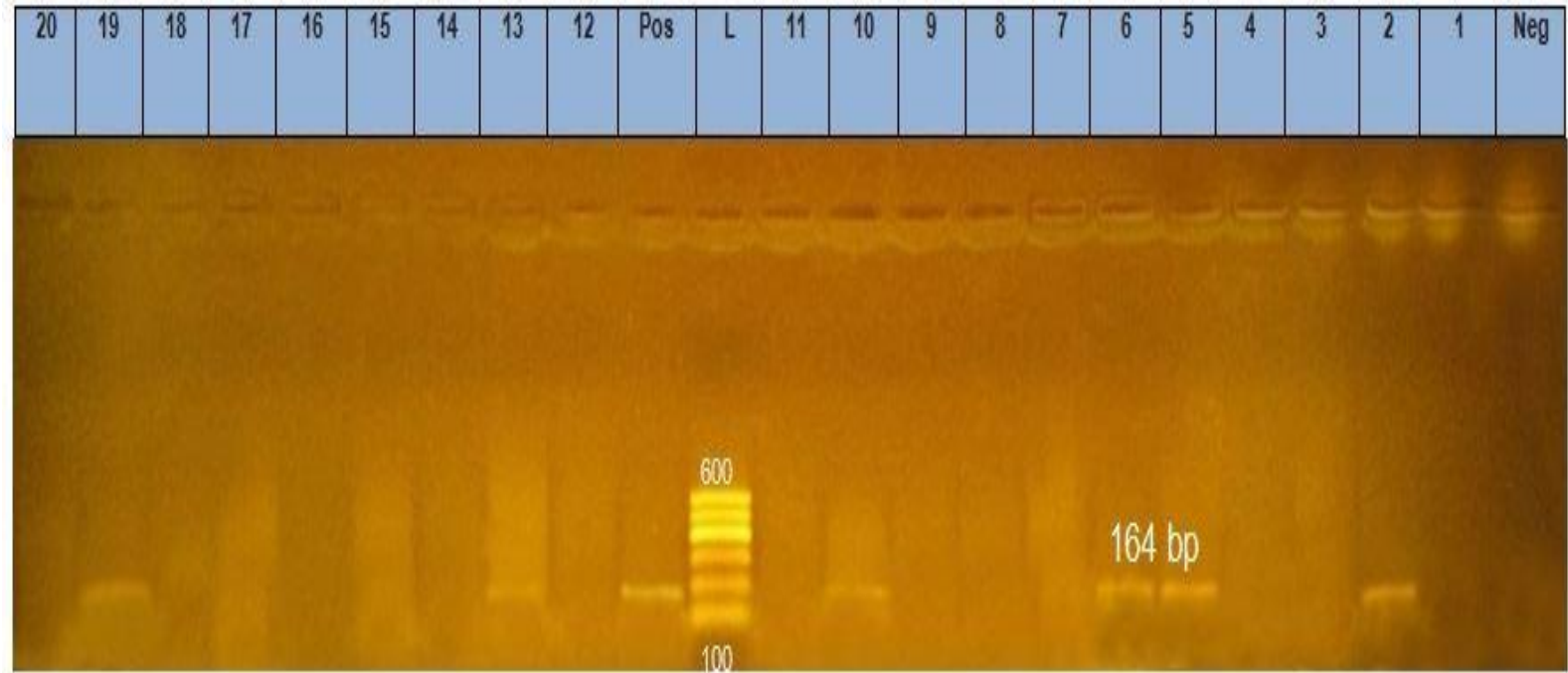

Figure (5): PCR results for $S$. aureus Seb gene.

L: $100-600$ bp DNA ladder

Lane 2,5,6,10, 13 and 19: positive samples For seb gene.

Lane 1, 3, 4, 7-9, 11,12, 14-18,20: negative samples

Pos. : Positive control

Neg. : Negative control

\section{DISCUSSION}

In the present study, Table (1) and Figures (1\&3) showed that $13(52 \%)$ and $16(64 \%)$ of raw cow's and bufallo's milk samples were contaminated by $S$. aureus respectively. Also revealed that the count of $S$. aureus in raw cow's milk ranged from $<10$ to $9.8 \times 10^{8}$ with a mean value of $1.62 \times 10^{8} \pm 9.5 \times 10^{7}$ $\mathrm{CFU} / \mathrm{ml}$ and the highest frequency distribution $(48 \%)$ was in a range of $<10$. The count of $S$. aureus in raw buffalo's milk ranged from $<10$ to $8.5 \times 10^{8}$ with a mean value of $7.88 \times 10^{7} \pm 5.19 \times 10^{7} \mathrm{CFU} / \mathrm{ml}$ and the highest frequency distribution $(36 \%)$ was in a range of $<10$.

To some extent nearly similar results for the incidence of $S$. aureus were postulated by Rall et al. (2008), De Oliveira et al. (2011), Charaya et al. (2014) and Pourtaghi et al. (2015). While higher results were reported by Gitau et al. (2010), Ayele et al. (2017) at farm level, and Kandil et al. (2018). On the other side, lower results were demonstrated by Abdou et al. (2016) and Matallah et al. (2019).

$S$. aureus is frequently found in raw milk and the infections of mammary gland (mastitis) represent a significant reservoir of toxigenic strains in raw milk. Storage of raw milk under high environmental temperature permitting growth of $S$. aureus can stimulate the production of their enterotoxin. This results highlights the unhygienic handling and inadequate personal hygiene as postulated by Meshref (2013).
The obtained results in Table (2) and Figures (2\&3) revealed that the count of $S$. aureus in kareish cheese ranged from $<10^{2}$ to $7.3 \times 10^{8}$ with a mean value of $8.68 \times 10^{7} \pm 2.61 \times 10^{7} \mathrm{CFU} / \mathrm{g}$ and an incidence of $68 \%$. The highest frequency distribution $(32 \%)$ was in a range of $<10^{2}$.

To some extent nearly similar results for the count were indicated by Ewida (2009) and Salama et al. (2015), with respect to the $S$. aureus incidence higher results were recorded by El-Kholy et al. (1995) and Kandil et al. (2018), but lower results were reported by Mousa (2017) and Abo ElMakarem and Amer (2018). While lower results for the count were recorded by Moawad et al. (2002), Al-Tahiri (2005), Bahout and Moustafa (2006), ElBessary (2006), Aly et al. (2007), Sadik (2009) and Armanios (2013).

S. aureus is frequently found in milk, however their presence in kareish cheese is usually due to primary contamination from raw milk, unhygienic handling of the cheese and/or on extensive contamination by personnel possibly involved in cheese making and marketing; as humans are the common carriers.

The high incidence of $S$. aureus in the examined kareish cheese was due to that the kareish cheese is made by farmers from raw milk that isn't subjected to heat treatment. Street vendors put kareish cheese in pans exposed to dust and flies (Zakary et al., 2011). So, kareish cheese are involved in food poisoning outbreak from public health point of view, 
S. aureus had been implicated in many cases of food poisoning and gastroenteritis among consumers (Eley, 1996).

The results in Table (2) and figures (2\&3) showed that the count of $S$. aureus in the examined small scale ice-cream ranged from $<10^{2}$ to $7.8 \times 10^{8}$ with a mean value of $6.64 \times 10^{7} \pm 3.29 \times 10^{7} \mathrm{CFU} / \mathrm{g}$ and an incidence of $80 \%$. The highest frequency distribution $(36 \%)$ was in a range of $10^{7}-<10^{8}$. To some extent nearly similar result for the count was pointed by Nawar (2001), but for the incidence was recorded by Ahmed et al. (2019). While higher result for incidence was reported by Kandil et al. (2018) and lower result for the count was detected by Ewida (2009).

It's noticed from the results in Table (2) and figures (2\&3) that the count of $S$. aureus in the examined large scale ice-cream ranged from $<10^{2}$ to $1.1 \times 10^{7}$ with a mean value of $6.52 \times 10^{5} \pm 4.41 \times 10^{5} \mathrm{CFU} / \mathrm{g}$ and an incidence of $24 \%$. The highest frequency distribution $(76 \%)$ was in a range of $<10^{2}$. Nearly similar result for the count of $S$. aureus was reported by Hassan (2015), while nearly result for the incidence of $S$. aureus was recorded by Abd ElFattah (2013). In addition to, lower result for the incidence was reported by El-Ansary (2015). From another side higher results for the incidence were detected by Zakary et al. (2011) and Kandil et al. (2018)

Ice-cream has been incriminated as a vehicle of staphylococcal enterotoxin in several food poisoning outbreaks as ice-cream mix was usually contaminated at the time of preparation and during the long period of cooling as well as before the mix freezing (APHA, 1992). The high contamination rates of examined ice-cream samples are mainly due to use poor quality of milk and materials used in icecream manufacture, environmental contamination as unclean hands of worker either suffering from diseased or apparent healthy carriers, unsanitary production and marketing practices (Araujo et al., 2002).

The results in Table (2) and figures (2\&3) revealed that the count of $S$. aureus in the examined small scale yoghurt ranged from $<10^{2}$ to $3.2 \times 10^{7}$ with a mean value of $3.67 \times 10^{6} \pm 1.68 \times 10^{6} \mathrm{CFU} / \mathrm{g}$ and an incidence of $88 \%$. The highest frequency distribution $(36 \%)$ was in a range of $10^{6}-<10^{7}$. Nearly similar result for the incidence was recorded by Abou El-Makarem (2013), while lower results for count and incidence were indicated by Hafez (2010) and Kandil et al. (2018).

In addition, the occurrence of $S$. aureus in the examined large scale yoghurt samples were present in $9(36 \%)$ and ranged from $<10^{2}$ to $8.50 \times 10^{6}$ with a mean value of $5.27 \times 10^{5} \pm 3.45 \times 10^{5} \mathrm{CFU} / \mathrm{g}$. The majority of the samples $16(64 \%)$ contained $<10^{2}$ $\mathrm{CFU} / \mathrm{g}$. To somewhat extent similar results were reported by Haggag (2006), Sadik (2009), El- Kholy et al. (2014) and Shahin (2015), while comparatively higher result for the incidence was noted by Ahmed et al. (2014), but lower result was obtained by Osman (2015). In contrast, no $S$. aureus were detected in any of the examined samples by ElBessery (2001), El-Kholy et al. (2016).

The variation between these results and the others was attributed to the difference in localities where samples were collected; also, there are different sources for contamination by $S$. aureus as from respiratory infections, skin or mouth of the workers handling the dairy products. So it's good indicator of the personal hygiene of the workers (Kamat et al., 1991). Finally, we should show that the high incidence of $S$. aureus is indicative of poor hygienic measures during production, handling and distribution (Joshi et al., 2004). The difference in prevalence rates of $S$. aureus between the examined products may originate from the method of manufacture, storage and handling. The lowest prevalence rate $(24$ and $36 \%$ ) of $S$. aureus which were recorded in large scale ice-cream and large scale yoghurt, respectively. This might be attributed to the effect of heating then freezing during their manufacturing which inhibit the multiplication of the microorganism and kill the microorganism (Zakary et al., 2011).

It's worth in mention that the presence of $S$. aureus in milk and dairy products even in low numbers must be regarded a public health hazard; because it has been established that the $S$. aureus may lose it's viability in food, but enterotoxuis still exit. The viability of $S$. aureus during the manufacturing of dairy products as cheese, yoghurt and ice-cream, depend on the addition of salt concentration, starter culture and storage time (Erkmen, 1995). The higher incidence in our results are due to the poor hygienic conditions during milking and cheese making and inappropriate conditions of their storage negatively influenced the cheese quality.

The results in Table (3) and Figures (4\&5) regarding that twenty $S$. aureus strains (5 out of milk samples and 5 of each product of kareish cheese, ice-cream and yoghurt samples) were examined for enterotoxin genes detection and $30 \%$ of the examined S. aureus strains were enterotoxigenic by PCR technique as carried one or two SE-genes. Sea gene is detected in yoghurt and milk for Sea and Seb genes by PCR samples with a percentage $20 \%$ of each while Sea was not detected in any ice-cream and kareish cheese samples. While Seb gene was found in 6 $(30 \%)$ of the strains isolated dairy products in this study. It was interesting that most of the $S$. aureus isolated from yoghurt and milk in our study harbored the Seb (40\%) gene, and the strains 
isolated from ice-cream and kareish cheese samples contained the Seb gene at level of $20 \%$. These results are similar to (Lee et al., 2001 and Peles et al., 2007).

While comparatively higher results for Sea gene than our obtained result in this study was recorded by (Mathenge et al., 2015), but lower results for Sea gene were reported by (Ghaleb et al., 2005 and Naffa et al., 2006). On the other hands, the higher result for Seb gene was recorded by (Ghaleb et al., 2005), but lower results for Seb gene were reported by (Mathenge et al., 2015 and Zouharova and Rysanek, 2008).

Although pasteurization destroy S. aureus pathogen, but thermostable SEs can resist heat treatment and still are potent even in very small amount ranging from $20 \mathrm{ng}$ to $<1 \mu \mathrm{g}$ can produce symptoms to human beings (Bergdoll, 2012). Enterotoxigenic strains of $S$. aureus have been reported to cause a number of diseases or food poisoning outbreaks due to ingestion of contaminated dairy products (Oliver et al., 2005). SEs have ability to withstand the environmental conditions such as drying, heat and freezing (Le Loir et al., 2003). In this study, we found enterotoxigenic $S$. aureus in yoghurt samples which has low acidity due to that the enterotoxins of $S$. aureus can survive at lowered $\mathrm{pH}$ and proteolytic enzymes such as pepsin or trypsin that destroy them completely functional in the gastrointestinal tract after consumed. They also are one of the superantigens family, which demolishes the immune system of the host by targeting the innate and adaptive system responses (Argudin et al., 2010).

Neither the absence of $S$. aureus nor the presence of small numbers of organism can provide complete assurance that the milk and dairy products are safe, since conditions inimical to the survival of $S$. aureus may result in a diminished population or death of viable microbial cells, while sufficient toxins remain to elicit symptoms of staphylococcal food poisoning (Bennett and Monday, 2003). Although foods must contain at least $10^{6}$ enterotoxigenic $S$. aureus $\mathrm{CFU} / \mathrm{g}$ to induce illness, small numbers of $S$. aureus present in thermally processed foods may represent the survivors of very large populations (Robinson and Tamime, 2002).

\section{CONCLUSION}

Results of this study clearly indicate that milk and milk products in the examined areas have high prevalence of $S$. aureus and found some secreated enterotoxins in this samples which lead to presence food poisoning symptoms, where we found that the small scale yoghurt and small scale ice-cream samples have higher contamination percentage with $S$. aureus then kareish cheese and raw milk samples than large scale yoghurt and large scale ice-cream samples have lower contamination level, and this due to poor hygienic handling, inadequate personnel hygiene and unsufficient pasteurization. So, It's required improving hygiene practices during milking routine and careful handling of animal during milking should be followed to limit the spread of $S$. aureus to humans and less than $100 \mathrm{cell} / \mathrm{ml}$ milk of bacterial counts can be achieved if some better hygienic practices implemented. Introduction of cooling system for the milk during production, transportation and during distribution process particularly during the summer season to not allow $S$. aureus to form SEs. Milk must be produced, distributed, handled and marketed under the control of milk commission and the commission must have a sanitary inspector and veterinarian to enforce its methods and standards.

\section{REFERENCES}

Abdou, M.S.; Ebied, N.A.; Elkassas, W.M. and ElGamal, A.M. (2016): Some pathogenic bacteria of public health importance in cow's milk sold in markets. Assiut Vet. Med. J., 62(149): 32-39.

Abdel-Fattah, S.A.N. (2013): Microbial profile of some dairy products. Ph. D., Thesis, Fac. Vet. Med. Alexandria Univ., Egypt.

Abo El-Makarem, H. and Amer, A. (2018): Multiplex PCR and Sandwich ELISA for identification of enterotoxigenic $S$. aureus isolated from Egyptian soft cheese. Fac. Vet. Med., Alexandria Univ., Egypt. Egyptian J. Food Safety., 2(1).

Abou El-Makarem, H.S.M. (2013): Biocontrol of some food borne pathogens isolated from traditional fermented milk. Ph. D., Thesis, Fac. Vet. Med., Alexandria Univ., Egypt.

Ahmed, L.I.; Morgan, S.D.; Hafez, R.S. and AbdelAll, A.A.A. (2014): Hygienic quality of some fermented milk products. Int. J. Dairy Sci., 9(8): 68-78.

Ahmed, A.A.; Maharik, N.M.S.; Valero, A. and kamal, S.M. (2019): Incidence of enterotoxigenic $S$. aureus in milk and Egyptian artisanal dairy products. Food Control., (104): 20-27.

Al-Tahiri, R. (2005): A comparison on microbial conditions between traditional dairy products sold in Karak and some products produced by modern dairies. Pakistan. J. Nutr., 4(5): 345348.

Aly, S.A.A.; Morgan, S.D. and Moawad, A.A. and Metwally, B.N. (2007): Effect of moisture, salt content and $\mathrm{pH}$ on the microbiological quality of traditional Egyptian Domiati cheese. Assiut Vet. Med. J., 53: 68-81.

APHA (1992): Standard methods for the examination of dairy products. $16^{\text {th }}$ ed., American Public Health Association, Washington. 
Araujo, V.S.; Pagliares, V.A.; Queiroz, M.L.P. and Freitas-Almeida, A.C. (2002): Occurrence of Staphylococcus and enteropathogens in soft cheese commercialized in the city of Rio de Janeriro, Brazil. J. Appl. Microbiol., 92: 1172-1177.

Argudin, M.A.; Mendoza, M.C. and Rodicio, M.R. (2010): Food poisoning and $S$. aureus enterotoxins. Toxins, 2 (7): 1751-1773.

Armanios, H.F.M. (2013): Sanitary evaluation of serving milk and dairy products in Alexandria University Hospitals. M. V. Sc., Thesis, Fac. Vet. Med., Alexandria Univ., Egypt.

Aycicek, H.; Cakiroglub, S. and Stevensonc, T.H. (2005): Incidence of $S$. aureus in ready to eat meals from military cafeterias in Ankara, Turkey. Food Control, 16: 531-534.

Ayele, Y.; Gutema, F.D.; Edao, B.M.; Girma, R.; Tufa, T.B.; Beyene, T.J.; Tadesse, F.; Geloye, M. and Beyi, A.F. (2017): Assessment of $S$. aureus along milk value chain and its public health importance in Sebeta, central Oromia, Ethiopia. BMC Microbiol., 17(1): 141.

Bahout, A.A. and Moustafa, A.H. (2006): Occurrence of some microorganism in relation to public health importance in kareish cheese. Assiut. Vet. Med. J., 52: 8296.

Balaban, N. and Rasooly, A. (2000): Staphylococcal enterotoxins. Int. J. Food Microbiol., 61: 110.

Bennett, R.W. and Monday, S.R. (2003): International Handbook of Food Borne Pathogens ( $S$. aureus). New York: Marcel Dekker, 240-58.

Bergdoll, M.S. (1983): Staphylococci and staphylococcal infections. New York, N.Y: Academic Press, Inc., pp.: 559-598.

Bergdoll, M.S. (2012): S. aureus. Food-Borne Bacterial Pathogens. Marcel Dekker, NewYork, pp.: 464-523.

Betley, M.J. and Mekalanos, J.J. (1987): Nucleotide sequence of the type A staphylococcal enterotoxin gene. J. Bacteriol., 170: 34-41.

Charaya, G.; Sharma, A.; Kumar, A.; Singh, M. and Goel, P. (2014): Pathogens isolated from clinical mastitis in Murrah buffaloes and their antibiogram, Veterinary World., 7(11): 980984.

De Oliveira, L.P.; Silva, V.C. and Cirqueira, M.G. (2011): Study of $S$. aureus in raw and pasteurized milk consumed in the Reconcavo area of the State of Bahia, Brazil. J. Food Processing and Technol., 2(6): 128.

El-Ansary, M.A. (2015): Hygienic quality of vanilla ice-cream sold at local markets. Alexandria J. Vet. Sci., 44(1): 54-58.

El-Bessary, M.M. (2006): Sanitary status of milk and some milk products marketed in suburbs of Assiut governorate, Ph. D., Thesis, Fac. Vet. Med., Assiut Univ., Egypt.

El-Bessery, M.M.A. (2001): Microbiological quality of market fermented milks in Assiut city. M.V.Sc., Thesis, Fac. Vet. Med. Assiut University.

El-Kholy, A.; El-Shinawy, S.; Hassan, G. and Morsy, B. (2016): Quality assessment and safety system of milk and some milk products in university hostel. Food Science and Quality Management, 50: 86-93.

El-Kholy, A.M.; El-Shinawy, S.H.; Meshref, A.M.S. and Korany, A.M. (2014): Screening of antagonistic activity of probiotic bacteria against some food-borne pathogens. Food Biosc. Technol. J., 34 (2): 1-14., Egypt.

El-Kholy, A.M.; Hafez, R.S. and Mahmoud, M.D. (1995): Occurrence of some food poisoning bacteria in Egyptian soft cheese. Beni-Suef Vet. Med. Res., 5(1): 342-355.

El-Sayed, M.A.; Hosny, I.M.; El-Kholy, W.I.; ElDairouty, R.K. and Mohamed, S.H.S. (2011): Microbiological evaluation of Egyptian white soft cheeses style. Amer. Sci. J., 7(5): 517526.

El-Sharef, N.; Ghanghesh, K.S.; Gnan, Y.A.S. and Rahouma, A. (2006): Bacteriological quality of ice cream in Tripoli-Libya. Food Control., 17(8): 637-641.

Eley, A.R. (1996): Microbial food poisoning. Springer publ., p: 33-73.

Erkmen, O. (1995): Behaviors of $S$. aureus in Turkish feta cheese during manufacture and ripening. J. Food Prot., 58(11): 1201-1205.

Ewida, R.M.M.A. (2009): Some studies on S. aureus in milk and some milk products sold in Assiut city with special reference to antibiotic resistance $S$. aureus. Ph. D., Thesis, Fac. Vet. Med. Assiut Univ., Egypt.

Ghaleb, A.; Bassam, A. and Kamel, A. (2005): Enterotoxigenic $S$. aureus in raw milk in the North of Palestine. Turk. J. Biol., (29): 229232.

Gitau, G.K.; Bundi, R.M.; Vanleeuwen, J. and Mulei, C.M. (2010): Mastitogenic bacteria isolated from dairy cows in Kenya and their antimicrobial sensitivity. J. South African Vet. Assoc., 85(1): 1-8.

Hafez, D.A.A. (2010): Sanitary condition of some processed milk products sold in Beni- Suef city. M. V. Sc., Thesis, Fac. Vet. Med., BeniSuef Univ., Egypt.

Haggag, Y.N. (2006): Public health importance of some bacterial pathogens isolated from milk and milk products. Suez canal Vet. Med. J., x. (1): 323-330.

Hassan. R.A.A. (2015): Detection of S. aureus and salmonella in some ready to eat dairy products using PCR. M. V. Sc., Thesis, Fac. Vet. Med., Zagazig Univ., Egypt. 
Joshi, D.R.P.K.; Shah, S.M.; Sharma, S. and Banmali, P. (2004): Microbial quality of icecream sold in Kathmandu. J. Nepal Health Res. Council., 2: 37-40.

Kamat, M.Y.; Sulebele, G. and Nirupama, S. (1991): A comparative evaluation of media for enumeration of enterotoxigenic staphylococci by selective enrichment technique. J. Food Sci. Technol., India, 28(6): 381-383.

Kandil, A.A.; El-Hadidy, M.; El-Gamal, A. and AlAshmawy, M.A. (2018): Identification of $S$. aureus and E-coli from dairy products intended for Human consumption. Adv. Anim. Vet. Sci., 6 (11): 509-513.

Lampert, L.M. (1987): Modern dairy products. $3^{\text {rd }}$ ed., Chemical Publishing Co., Inc., New York.

Lee, H.J.; Suh, T.J.; Kim, S.Y.; Lenz, W.; Bierbaum, G. and Schaal, K.P. (2001): Typing and antimicrobial susceptibilities of methicillin resistant $S$. aureus (MRSA) strains isolated in a hospital in Korea. J. Korean Med. Sci., 16: 381-385.

Le Loir, Y.; Baron, F. and Gautier, M. (2003): S. aureus and food poisoning. Genetics and Molecular Res., 2(1): 63-76.

Mahmoud, S.F.; El-Halmouch, Y. and Montaser, M.M. (2013): Effect of probiotic bacteria on Karish Cheese production. Life Sci. J., 10(2): 1279-1284.

Matallah, A.M.; Bouayad, L.; Boudjellaba, S.; Mebkhout, F.; Hamdi, T.M. and RamdaniBouguessa, N. (2019): S. aureus isolated from selected dairies of Algeria: Prevalence and susceptibility to antibiotics. Vet. World; 12(2): 205-210.

Mathenge, J.M; Okemo, P.O.; Nganga, P.M.; Mbaria, J.M. and Gicheru, M.M. (2015): Identification of enterotoxigenic $S$. aureus strains from meat and dairy products by multiplex PCR and reverse passive latex agglutination test in Nairobi, Kenya. East and Central Africa Med. J., 2: 97-103.

Mehrotra, M.; Wang, G. and Johnson, W.M. (2000): Multiplex PCR for Detection of Genes for $S$. aureus enterotoxins, Exfoliative Toxins, Toxic Shock Syndrome Toxin 1, and Methicillin Resistance. J. Clin. Microbiol., 38: (3).

Meshref, A.M.S. (2013): Bacteriological quality and safety of raw cow's milk and fresh cream. Slovenian Vet. Res., 50(1): 21-30.

McDonagh, D.; Lowless, F.; Gardiner, E.; Ross, R.P.; Stanton, C. and Donnelly, W.J. (1997): Milk and Milk products for better human health. Dairy quality department, DPRC,Teagasc, Moorepark, Fermoy. pp.: 1416.

Moawad, A.A.; Galal, E.A.; Abd El-Hady, H.M. and Dardir, H.A. (2002): Role of dairy plant in improving some aspects of kareish cheese. Egypt. Vet. Med. Ass., 62(2): 157-165.

Mousa, W.S.; Abdeen, E.; Hussein, H. and Hadad, G. (2017): Prevalance and Multiplex PCR for enterotoxin genes of $S$. aureus isolates from subclinical mastitis and kareish cheese. J. Infect. Dis. Preve. Med., 5:4

Naffa, R.G.; Bdour, S.M.; Migdadi, H.M. and Shehabi, A.A. (2006): Enterotoxicity and genetic variation among clinical $S$. aureus isolates in Jordan. J. Med. Microbiol., (55): 183-187.

Nawar, D.M.M. (2001): Hygienic quality of some street vended dairy products. M. V. Sc., Thesis, Fac. Vet. Med., Alexandria Univ., Egypt.

Oliver, S.P.; Jayarao, B.M. and Almeida, R.A. (2005): Food Borne Pathogens in milk and the dairy farm environment: Food Safety and Public Health Implications. Food Borne Path. Dis., 2(2): 115-129.

Omoe, K.; Machiko, I.; Shimoda, Y.; Dong-Liang, $H$. and Ueda, S. (2002): Detection of seg, she and sei genes in $S$. aureus isolates isolated from cows with mastitis and bovine raw milk and determination of the enterotoxin productivities of the $S$. aureus isolates harboring seg, she or sei genes. J. Clin. Microbiol., 40: 857-862.

Orwin, P.M.; Leung, D.Y.; Donahue, H.L.; Novick, R.P. and Schlievert, P.M. (2001): Biochemical and biological properties of staphylococcal enterotoxi K. Infect. Immun; 69: 360-366.

Osman, O.M.M. (2015): Quality evaluation of some fermented milk sold at local markets. Ph. D., Thesis, Fac. Vet. Med., Alexandria Univ., Egypt.

Peles, F.; Wanger, M.; Varga, L.; Hein, I.; Rieck, P.; Gutser, K.; Keresztúri, P.; Kardos, G.; Turcsányi, I.; Béri, B. and Szabó, A. (2007): Characterization of $S$. aureus strains isolated from bovine milk in Hungary. Int. J. Food Microbiol., 118: 186-193.

Pourtaghi, H.; Ghasem, A. and Sodagari, H.R. (2015): Antimicrobial resistance patterns of $S$. aureus isolated from bovine subclinical mastitis in alborz province, iran. Bulgarian $\mathrm{J}$. Vet. Med., ISSN 1311-1477.

Quinn, P.J.; Carter, M.E.; Markey, B.K. and Carter, G.R. (1994): Clinically veterinary microbiology. The Streptococci and related cocci. Wolfe Publishing an imprint of Mobsy Year book. Europe Limited.

Rall, V.L.M.; Vieira, F.P.; Rall, R.; Vieitis, R.L.; Fernandes, J.A.; Candeias, J.G.; Cardoso, K.F.G. and Araujo, J.J.P. (2008): PCR detection of staphylococcal enterotoxin genes in $S$. aureus strains isolated from raw and pasteurized milk. Vet. Microbiol., 132(3-4): 408-413. 
Richter, R.L.; Ledford, R.A.; Murphy, S.C.; Vanderzant, C. and Splittstoesser, D.F. (1992): Compendium of Methods for the Microbiological Examination of Foods (Milk and milk products). $3^{\text {rd }}$ ed., Washington: American Public Health Association, 837-56.

Robinson, R.K. and Tamime, A.Y. (2002): Maintaining a clean working environment. In: Robinson, R.K. (Ed.), Dairy Microbiology Handbook, the Microbiology of Milk and Milk Products, $3^{\text {rd }}$ ed., Wiley, New York, pp.: 561-591.

Sadik, S.M. (2009): Granding quality of some locally manufactured ice cream with special reference to $S$. aureus. M. V. Sc., Thesis, Fac. Vet. Med., Alexandria Univ., Egypt.

Salama, E.M.; Saad, A.H.; Enan, G.A. and Suzan, I.Y. (2015): Incidence and Biocontrol of $S$. aureus in some milk Products. 2nd Conference of Food Safety, Suez Canal University, Fac. Vet. Med., Volume I, pp.: 29-35.

Sambrook, J.; Fritscgh, E.F. and Mentiates (1989): Molecular coloning. A laboratory manual. Vol !., Cold spring Harbor Laboratotry press, New York.
Shahin, H.F.A. (2015): Sanitary evaluation of curd dairy products, M.V.Sc., Thesis, Fac. Vet. Med, Alexandria Univ., Egypt.

Shijia, W.U.; Duan, N.; Huajie, G.U.; Hao, L.; Gong, W. and Wang, Z. (2016): A review of the methods for detection of $S$. aureus enterotoxins. Toxins, 8 (176): 1-20.

Tranter, H.S. (1990): Food borne Staphylococcal illness. Lancet, 336, 1044-1046.

Wauschkuhm, B. (1970): The importance of yeasts in keeping quality of fresh cheese. XVIII Int. Dairy Cong., 338.

Wollowski, I.; Rechkemmer, G. and Pool-Zobel, B.L. (2001): Protective role of probiotics and probiotics in colon cancer. American J. Clin. Nut., 73(Suppl): 4515-4555.

Zakary, E.M.; Nassif, M.Z. and Mohammed, J.M.O. (2011): Detection of $S$. aureus in bovine milk and its product by Real Time PCR Asssy. Global J. Biotechnology and Biochemistry, 6 (4): 171-177.

Zouharova, M. and Rysanek, D. (2008): Multiplex PCR and RPLA identification of $S$. aureus enterotoxigenic strains from Bulk Tank milk. Zoonoses and Public Health, 55(6): 313-319.

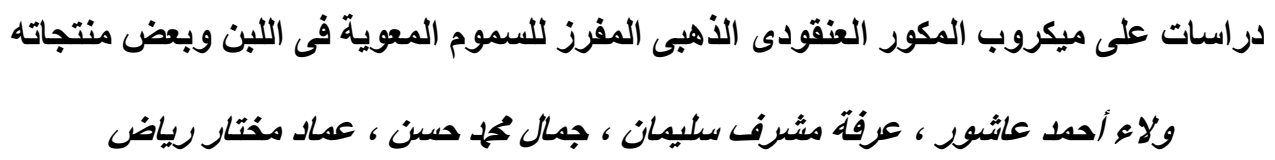

E-mail: ashour.walaa91@yahoo.com Assiut University web-site: www.aun.edu.eg

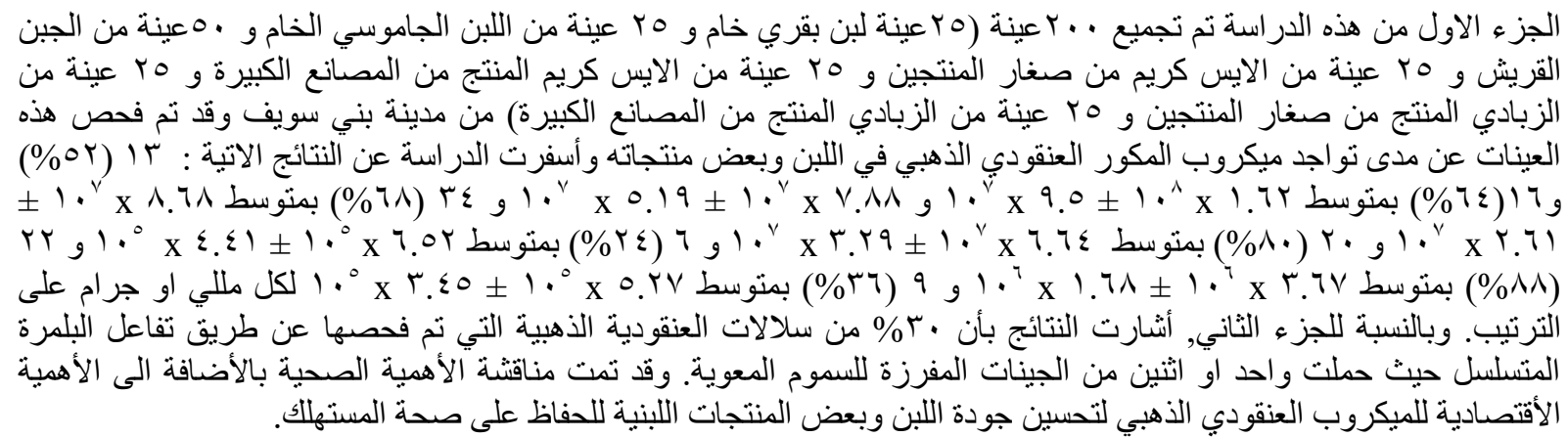

